\title{
EPSL
}

Earth and Planetary Science Letters 164 (1998) 285-302

\section{Towards a better definition of the Middle Triassic magnetostratigraphy and biostratigraphy in the Tethyan realm}

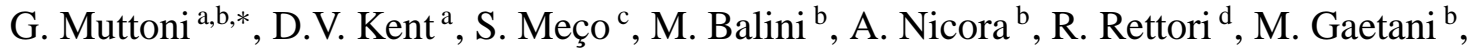 \\ L. Krystyn ${ }^{\mathrm{e}}$ \\ ${ }^{a}$ Lamont-Doherty Earth Observatory, Palisades, NY 10964, USA \\ ${ }^{b}$ Dipartimento di Scienze della Terra, Università di Milano, via Mangiagalli 34, I-20133 Milan, Italy \\ ${ }^{c}$ Fakulteti i Gjeologjise-Minierave, Universiteti Politeknik, Tirana, Albania \\ ${ }^{d}$ Dipartimento di Scienze della Terra, Piazza Università, I-06100 Perugia, Italy \\ ${ }^{e}$ Paläontologisches Institut, Universitätsstrasse 7, A-1010 Vienna, Austria
}

Received 28 October 1997; revised version received 21 September 1998; accepted 21 September 1998

\begin{abstract}
Magnetostratigraphic and biostratigraphic data for the Middle Triassic (Anisian) were obtained from the Han-Bulog facies in the Nderlysaj section from the Albanian Alps and the Dont and Bivera formations in the Dont-Monte Rite composite section from the Dolomites region of northern Italy. The Nderlysaj section is biochronologically bracketed between the late Bithynian and early Illyrian substages (i.e., late-early and early-late Anisian), whereas the Dont-Monte Rite section comprises the late Pelsonian and the early Illyrian substages. The data from Nderlysaj and Dont-Monte Rite, in conjunction with already published data, allow us to construct a nearly complete composite geomagnetic polarity sequence tied to Tethyan ammonoid and conodont biostratigraphy from the late Olenekian (late-Early Triassic) to the late Ladinian (late-Middle Triassic). New conodont data require revision of the published age of the Vlichos section (Greece). (C) 1998 Elsevier Science B.V. All rights reserved.
\end{abstract}

Keywords: magnetostratigraphy; biostratigraphy; Middle Triassic; Albania; Dolomites

\section{Introduction}

This paper presents new magnetostratigraphic (GM, DVK) and biostratigraphic (AN, SM, RR) data from the Anisian (Middle Triassic) Nderlysaj section from the Albanian Alps. The geology of the Nderlysaj region was also mapped in detail, and the

\footnotetext{
${ }^{*}$ Corresponding author. Present address: Institute of Geophysics, ETH-Hönggerberg, CH-8093 Zürich, Switzerland Tel.: +41 (1) 633-2633; Fax: +41 (1) 633-1065; E-mail: giom@mag.ig.erdw.ethz.ch
}

regional stratigraphy was better defined (MG). Additional magnetostratigraphic (GM, DVK) and biostratigraphic (MB, AN) data are also presented from the Dont-Monte Rite composite section from the Dolomites, Italy. These sections partly straddle a gap of magnetostratigraphic data between the Olenekian/ Anisian [1] and the Anisian/Ladinian boundary sections ([2], with new data by LK from this study), thus allowing us to construct a composite geomagnetic polarity sequence tied to Tethyan ammonoid and conodont biostratigraphy which covers nearly all of the Middle Triassic time interval. 


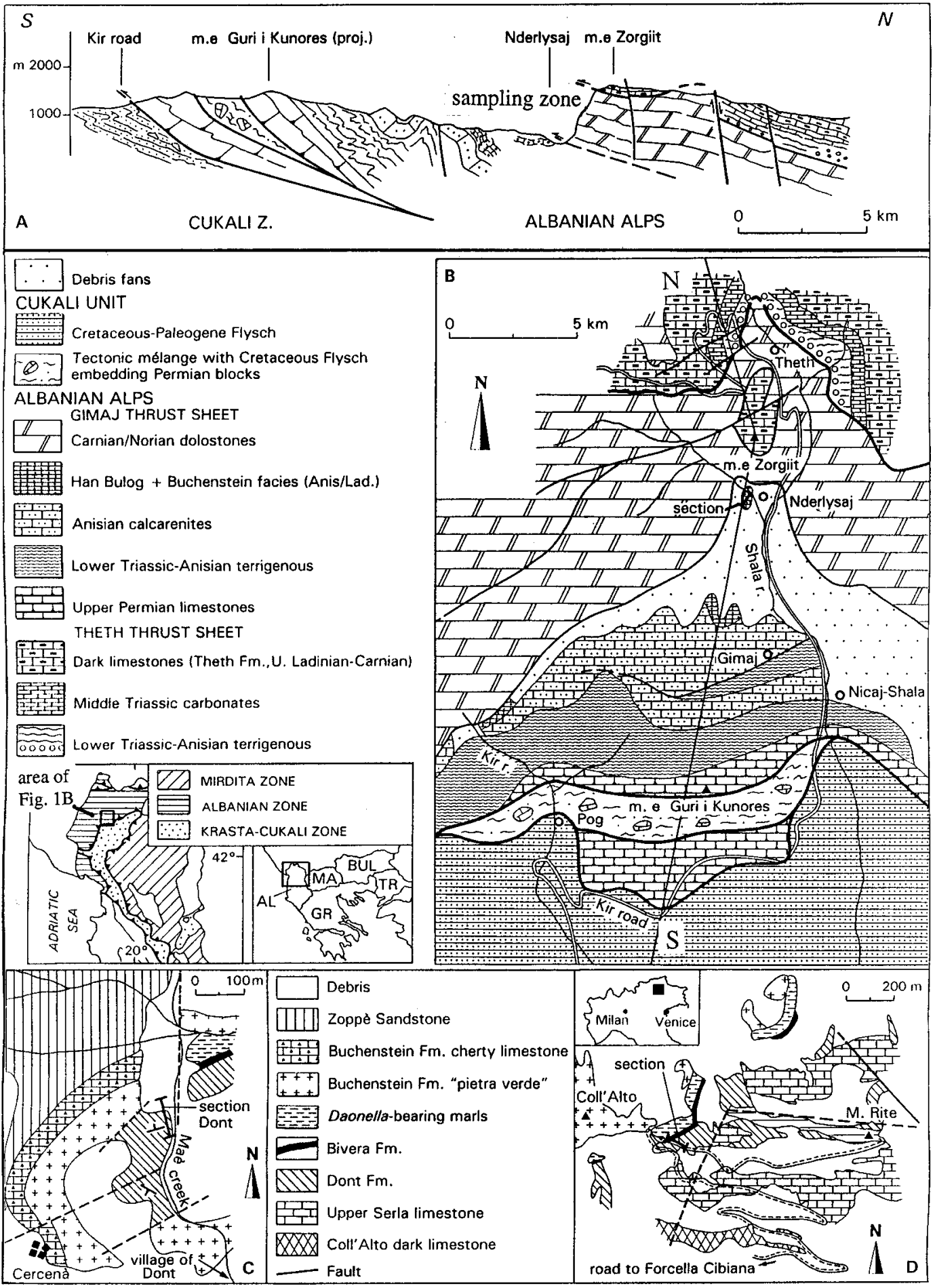




\section{The Nderlysaj section, Albanian Alps}

\subsection{Geology and lithology}

The Nderlysaj section is located in the Albanian Alps (Fig. 1A,B), which is a fold-and-thrust belt consisting of a minimum of five superposed thrust sheets comprised of Permian to Cretaceous rocks. These thrust sheet units were thrust to the southeast onto the Cukali Zone during the Alpine orogeny $[3,4]$, and were successively disrupted and faulted by the reactivation of the Skodre-Pec Fault system which acted as a pivot for the clockwise rotation of the Albanides during the Cenozoic [5-7].

The main boundary thrust, which brings the Albanian Alps to override as a whole the Cukali Zone, is exposed across the valley of the Shala River (Fig. 1B). The thrust sole is severely delaminated, such that slivers of Cretaceous flyschoid sediments associated with the Cukali Zone are tectonically embedded within Upper Permian rocks of the Albanian Alps. The Gimaj Unit is the lowest in the Albanian Alps tectonic pile and shows a succession spanning the Late Permian to Late Triassic time interval [Gaetani et al., in prep.]. In the study area, the Anisian succession is mostly calcarenitic to the south (e.g., at Gimaj, Fig. 1B), where carbonate banks produced abundant skeletal debris, and becomes progressively more pelagic toward the north (e.g., Han-Bulog facies at Nderlysaj) where mainly reddish nodular limestones were deposited.

The 46-m-thick Nderlysaj section sampled in this study has a lower portion rich in calcarenite beds and an upper portion dominated by pink nodular limestones. From the base upward it consists of (Fig. 2): (i) $5.2 \mathrm{~m}$ of grey to pink weakly nodular limestones intercalated with two finely graded calcarenite levels; (ii) $10.5 \mathrm{~m}$ of finely graded calcarenite beds associated with grey weakly nodular limestones; (iii) $8.5 \mathrm{~m}$ of grey calcarenite limestones and subordinate grey to pink calcilutite levels; (iv) $2.8 \mathrm{~m}$ of pinkish nodular limestones which are amalgamated to form metre-thick composite layers; (v) $1.2 \mathrm{~m}$ of decime- tre-thick pink and well subdivided nodular limestone beds intercalated with rare fine-grained calcarenites; (vi) $11.3 \mathrm{~m}$ of pinkish amalgamated nodular limestone beds intercalated with calcarenites; (vii) $1.4 \mathrm{~m}$ of pinkish limestones intercalated with fine-grained calcarenites; (viii) $5.3 \mathrm{~m}$ of thinly bedded grey to pink nodular limestone beds.

The calcarenite beds are bioclastic fine-grained packstones and grainstones of carbonate platform origin containing benthic foraminifers, algal lumps, dasyclades fragments, Tubyphites spp., gastropods, bivalves and undetermined encrusting organisms. The pink nodular limestone beds are basinal packstones and wackestones containing radiolarians, thinshelled bivalves, ostracods, sponge spicules, echinoderm fragments and rare Nodosariidae.

\subsection{Biochronology}

Ammonoids are only rarely present and, when present, they are highly deformed. The biostratigraphic control of the section is based on conodonts and, to a lesser extent, benthic foraminifers. Conodonts of typically Anisian age with a colour alteration index of 3 to 4 were recognized throughout the section (Fig. 2). The basal $1.5 \mathrm{~m}$ of the section, which contain Gondolella bulgarica among other conodont taxa, are attributed to the late Bithynian (i.e., the second substage of the Anisian). The first occurrence (FO) of undoubted specimens of Neospathodus kockeli was recorded at metre 1.5 and approximates the base of the Pelsonian according to Kovács and Kozur [8] and Sweet [9]. The FO of G. cornuta at metre 38 is a proxy for the base of the Illyrian (i.e., the last substage of the Anisian). The Nderlysaj section thus covers the late Bithynian to early Illyrian time interval. The vertical sequence of the biochronologically significant events does not appear to have been altered by major sedimentation gaps or faulting, although a minor break in sedimentation may occur at metre 24.

Benthic foraminifers were recorded mainly in calcarenite levels of carbonate platform origin. Pil-

Fig. 1. (A) Geological cross-section of the Nderlysaj area in the Albanian Alps. (B) Geological map of the Nderlysaj area with simplified geological map of northern Albania in the Balkan Peninsula; $N-S$ is the location of the cross-section of panel (A). (C) Geological map of the Dont. (D) Monte Rite areas from the Dolomites, Italy. 


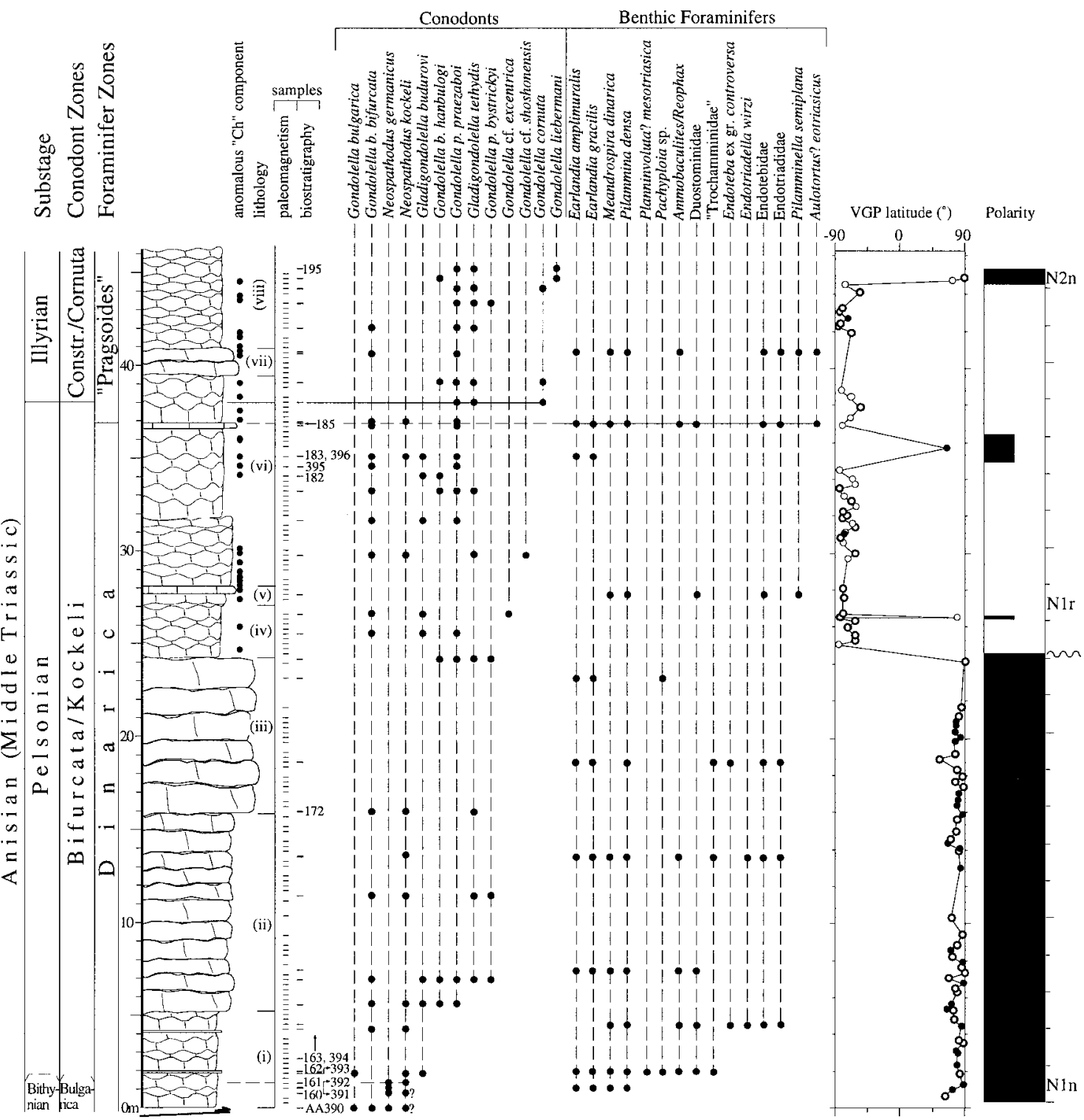

Fig. 2. The Anisian Nderlysaj section. The lithostratigraphic subdivisions are reported in roman numbers to the right of the lithology column and are described in the text. The age determination of the section is based on conodont and, to a lesser extent, benthic foraminifer biostratigraphy. To the right of figure is a plot of relative VGP latitudes of the characteristic component as a function of stratigraphic position with polarity interpretation. Filled (plain open) circles are VGP relative latitudes of the stable endpoint characteristic remanence carried by magnetite (mainly hematite) as determined from unblocking characteristics of NRM. Bold open circles are VGP relative latitudes of the characteristic remanence obtained with the great circles technique as discussed in the text (for these samples the mineralogy cannot be inferred from unblocking characteristics of NRM). Magnetic polarity zones are shown by filled (open) bars for normal (reversed) polarity; single-sample polarity zones are shown by half bars. The stratigraphic positions where the 'D' component directions were found are reported at the side of the lithology column. 
ammina densa and Meandrospira dinarica occur throughout the section except for sample AA174 (Fig. 2). The first occurrence of Pilamminella semiplana sensu Rettori [10] and Aulotortus? eotriasicus were recorded at metre 27.7 (sample AA178) and 36.85 (sample AA185), respectively.

The $M$. dinarica-P. densa assemblage is well known in the Anisian of the Tethys [10-12]. The P. densa Range Zone (RZ) was introduced by Salaj [13] for the late Anisian of the West Carpathians. This zone, redefined by Salaj et al. [14], is Bithynian pro parte to Illyrian in age and is comprised between the first appearance (FA) of P. densa, and the FA of Pilamminella gemerica or Aulotortus sinuosus. The P. densa RZ is subdivided, from base to top, into the M. dinarica Interval Subzone (IS) of Bithynian pro parte to Pelsonian age, and the A. pragsoides IS of Illyrian age [14].

We suspect that the Anisian species A. pragsoides of the West Carpathians (= Permodiscus pragsoides sensu Salaj et al. [15]) could in fact be A.? eotriasicus. Some large involutinids associated with $M$. dinarica and $P$. densa, which in the past were often referred to as $A$. pragsoides [16,17], are nowadays included in the morphologically similar species A.? eotriasicus. The type material of A.? eotriasicus comes from the Anisian of the Dinarids [16,18], and was also recently found on Hydra (Greece) in association with Pelsonian conodonts [19]. The microfaunal assemblage where A.? eotriasicus was found matches that where Salaj et al. [14] found ' $A$. pragsoides'.

We consider A. pragsoides sensu Salaj et al. [14] as synonymous with A.? eotriasicus, and therefore suggest that the lower boundary of the A. pragsoides IS (= A.? eotriasicus IS) should be referred to the Pelsonian, while the upper boundary is Illyrian according to Salaj et al. [14]. We conclude that the interval at Nderlysaj up to about metre 36.85 and containing $P$. densa and $M$. dinarica could be generically referred to the M. dinarica IS of Bithynian pro parte to Pelsonian age, whereas upwards the section can be attributed to the lower part of the Pelsonian to Illyrian 'A. pragsoides' IS (= A.? eotriasicus IS), in broad agreement with conodont biostratigraphy.

\subsection{Palaeomagnetic properties}

Samples from Nderlysaj were drilled in the field and studied in the palaeomagnetics laboratory of Lamont-Doherty with similar techniques as described elsewhere (e.g., [1]). The section was sampled at an average interval of $30 \mathrm{~cm}$ giving a total of 149 standard $11 \mathrm{~cm}^{3}$ specimens for analysis. The natural remanent magnetization (NRM) intensity is on average one order of magnitude lower in the lower mainly calcarenite part of the section than in the upper pinkish nodular part (i.e., 0.09 vs. $0.7 \mathrm{~mA} /$ $\mathrm{m})$. The magnetic susceptibility is generally low and conforms to this NRM intensity trend. The thermal unblocking characteristics of orthogonal-axes isothermal remanent magnetization (IRM) [20] show that the calcarenite beds are dominated by magnetite, coexisting with subsidiary hematite, whereas the magnetic properties of the pinkish nodular limestone beds are dominated by hematite.

Samples typically show the presence, in in-situ coordinates, of a low unblocking temperature ' $\mathrm{A}$ ' component of steep positive inclination consistent with viscous acquisition biassed toward the presentday field direction. In the temperature range between about $200^{\circ} \mathrm{C}$ and $500^{\circ} \mathrm{C}$, a 'B' component overprint with in situ west-southwest and negative directions was resolved by means of least-square line-fits [21] on the linear portion of vector endpoint demagnetization diagrams in $91 \%$ of the specimens (Fig. 3a-d). A dual-polarity characteristic (' $\mathrm{Ch}$ ') component of magnetization, moderately shallow with either northeast and negative or southwest and positive directions, was obtained by least-square analysis in $29 \%$ of the specimens. The maximum unblocking temperatures of the ' $\mathrm{Ch}$ ' magnetization are compatible with magnetite and/or hematite as the remanence carrier (Fig. 3a,b). In 35\% of the specimens, the 'Ch' component could not be completely isolated since successive demagnetization steps moved the remanence vector along a great circle from the ' $\mathrm{B}$ ' towards the 'Ch' direction (Fig. 3c). Therefore, the combined analysis of remagnetization great circles and direct observations [22] was applied to determine the 'Ch' component directions of the NRM. Finally, in $18 \%$ of the specimens there occurred northwest and positive stable endpoint directions which were unblocked after the ' $\mathrm{B}$ ' directions between about $600^{\circ} \mathrm{C}$ 
a)
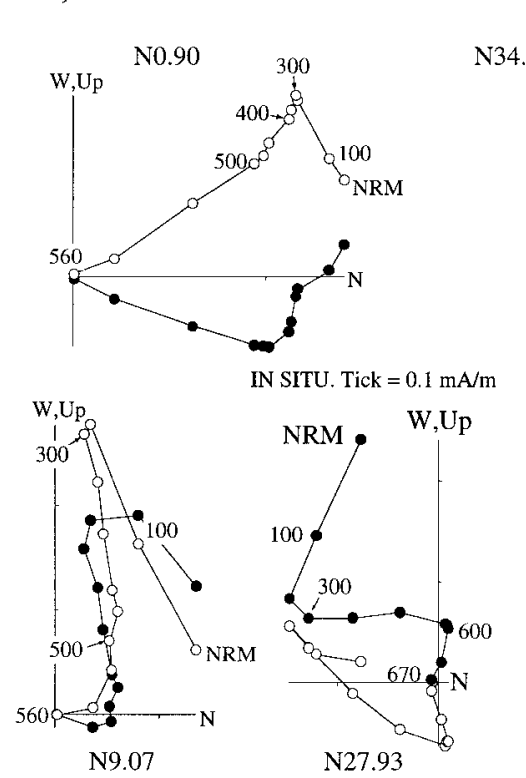

c)
IN SITU. Tick $=0.1 \mathrm{~mA} / \mathrm{m}$

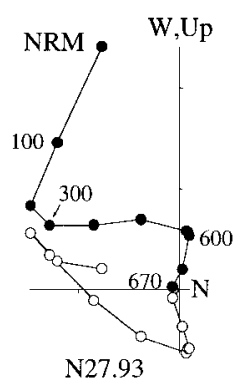

d) b)
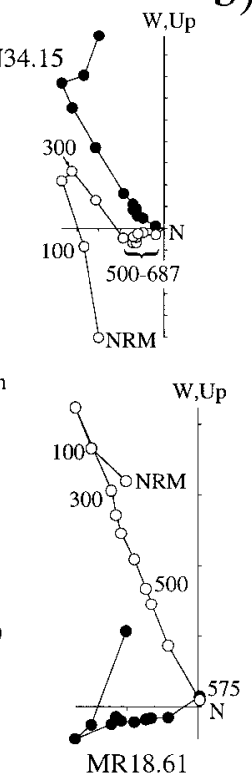

e)

Fig. 3. Zijderveld thermal demagnetograms of NRM of representative samples from Nderlysaj with normal (a) and reversed (b) polarity characteristic magnetizations. Sample in panel (c) is an example of overlapping ' $\mathrm{B}$ ' and characteristic component spectra. Sample in panel (d) is an example of ' $D$ ' component. Sample in panel (e) is from Monte Rite. Closed symbols are projections onto the horizontal plane and open symbols are projections onto the vertical plane in in-situ coordinates. Demagnetization temperatures in ${ }^{\circ} \mathrm{C}$.

and $680^{\circ} \mathrm{C}$, i.e., in the same temperature range of the bipolar 'Ch' component (Fig. 3d). These 'D' component directions are concentrated in the upper nodular half of the section (Fig. 2, black dots at the side of the lithology column). Comparison of the distribution of the present-day field ('A') and 'D' directions in in-situ coordinates suggests a possible common origin for both components (Fig. 4a). It is therefore possible that the ' $\mathrm{D}$ ' component represents the high unblocking temperature tail of the present-day field component, perhaps due to weathering and creation of new hematite (see panel onto ' $\mathrm{D}$ ' component in Fig. 4a).

The different directions, determined with standard Fisher statistics, change by about the same amount with correction for bedding tilt (bedding attitude varying from azimuth of $\operatorname{dip} / \operatorname{dip} 184^{\circ} \mathrm{E} / 59.5^{\circ}$

at the base to $227^{\circ} \mathrm{E} / 33^{\circ}$ at the top). In particular, the stable endpoint bipolar ' $\mathrm{Ch}$ ' component turns to northeast positive or southwest negative on application of bedding tilt correction (Fig. 4a; Table 1). The stable endpoint normal and reversed mean directions are displaced from antipodality by $15.7^{\circ}$ probably because of unresolved contamination of the characteristic magnetizations by the ' $\mathrm{B}$ ' component, and do not pass the reversal test. By combining data from remagnetization great circles and direct observations we were able to determine the overall mean normal and reversed ' $\mathrm{Ch}$ ' directions (Fig. 5; Table 1), which however still deviate from antipodality by $19.4^{\circ}$ in bedding coordinates. In order to minimize the biassing effect due to contamination, we invert to common normal polarity the reversed mean directions and calculate an average value of Decl. $=28.9^{\circ}$, Incl. $=27.3^{\circ}$ which indicates an Anisian palaeolatitude of about $14^{\circ} \mathrm{N}$ for the Nderlysaj region.

A virtual geomagnetic pole (VGP) was calculated for each ' $\mathrm{Ch}$ ' component stable endpoint direction after correction for bedding tilt. In those cases where a stable endpoint could not be reached, we calculated the VGP of the unit vector on the great circle closest to the normal or reversed mean ' $\mathrm{Ch}$ ' direction. The latitude of the specimen VGP with respect to the overall mean north palaeomagnetic pole was used to delineate the magnetic polarity stratigraphy [23]. VGP relative latitudes approaching $+90^{\circ} \mathrm{N}\left(-90^{\circ} \mathrm{N}\right)$ are interpreted as recording normal (reversed) polarity. For polarity magnetozone identification, we adopt the nomenclature used by Kent et al. [23]. The latitude of the VGPs defines at Nderlysaj a lower normal (N1n)-reversed (N1r)-normal (N2n) polarity sequence (Fig. 2). The N1n/N1r boundary falls at about metre 24 where a lithological and mineralogical transition is also observed; we therefore suspect the presence here of a hiatus whose duration should not however be very long as it is not revealed by the sequence of biostratigraphic data.

\section{The Dont-Monte Rite section, Dolomites}

\subsection{Geology and lithology}

The Dont-Monte Rite composite section consists of two partially overlapping sections outcropping in 


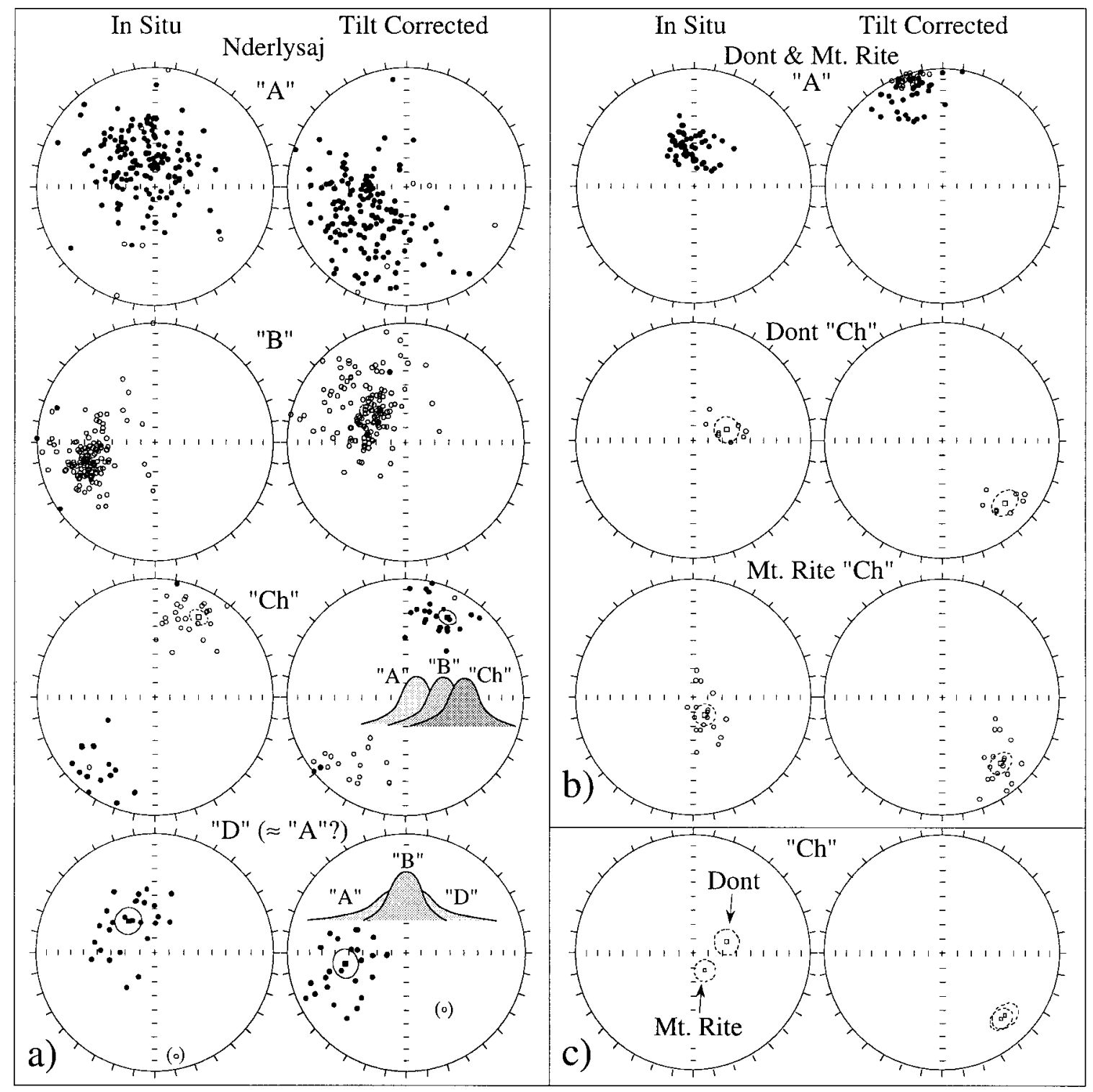

Fig. 4. Equal-area projections before (in situ) and after bedding tilt correction of (a) the 'A', 'B', 'Ch' and 'D' component directions from Nderlysaj, (b) the 'A' and 'Ch' component directions from Dont and Monte Rite, and, finally, of (c) the Dont and Monte Rite 'Ch' mean directions. See text for discussion.

the eastern Dolomites. The Dont section, exposed near the Village of Dont (Fig. 1C), contains the oldest strata, and the Monte Rite section, located a few kilometres north of Dont (Fig. 1D), contains the youngest strata. The Dont-Monte Rite composite section encompasses a stratigraphic interval of
Anisian age which is comprised of, from base to top, the Dont and Bivera formations (Fig. 6). The Dont section is $16.1-\mathrm{m}$-thick and is entirely comprised of the Dont Fm. which is informally subdivided into a lower terrigenous member consisting of centimetreto decimetre-thick beds of sandy limestones interca- 


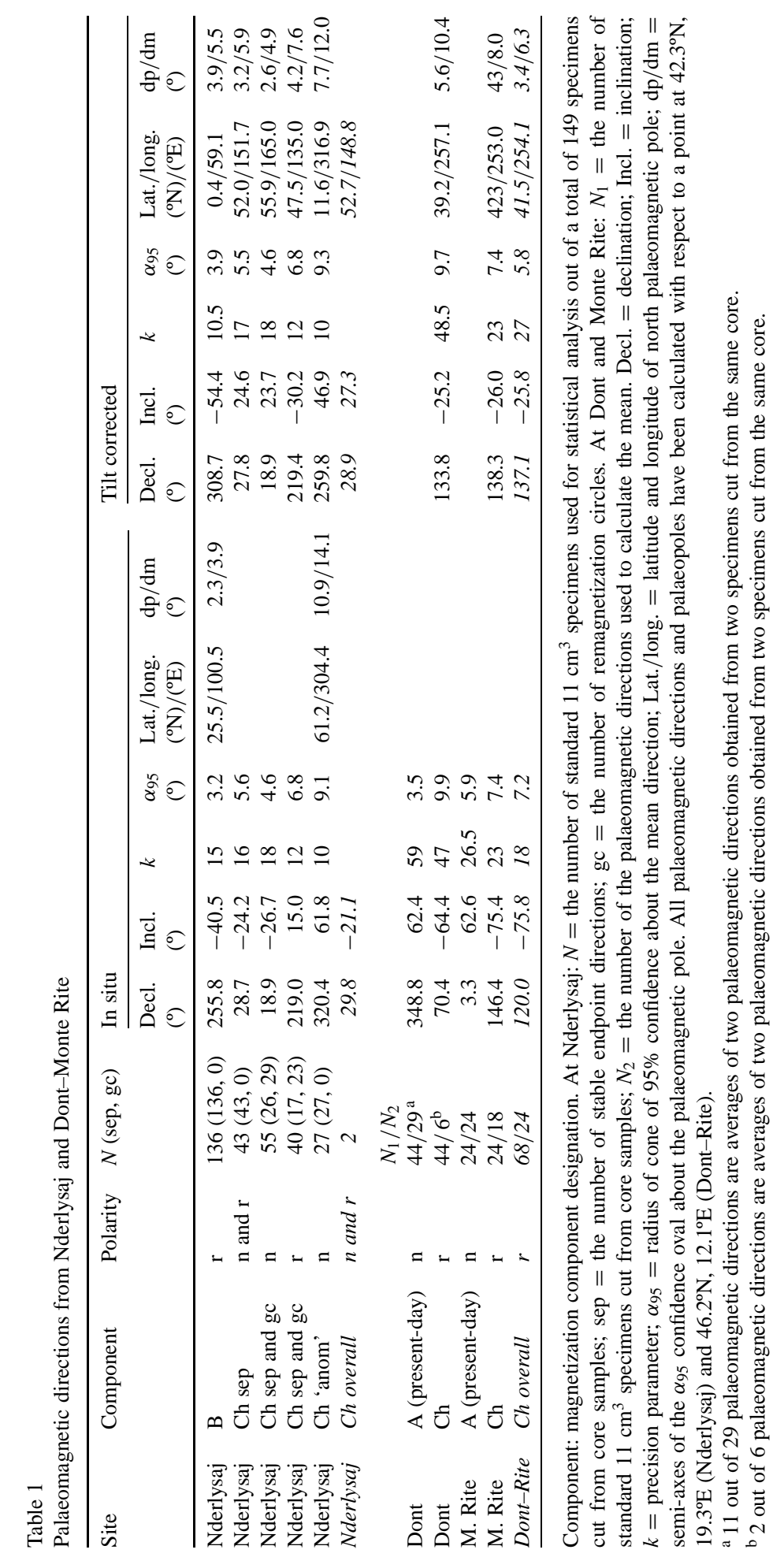




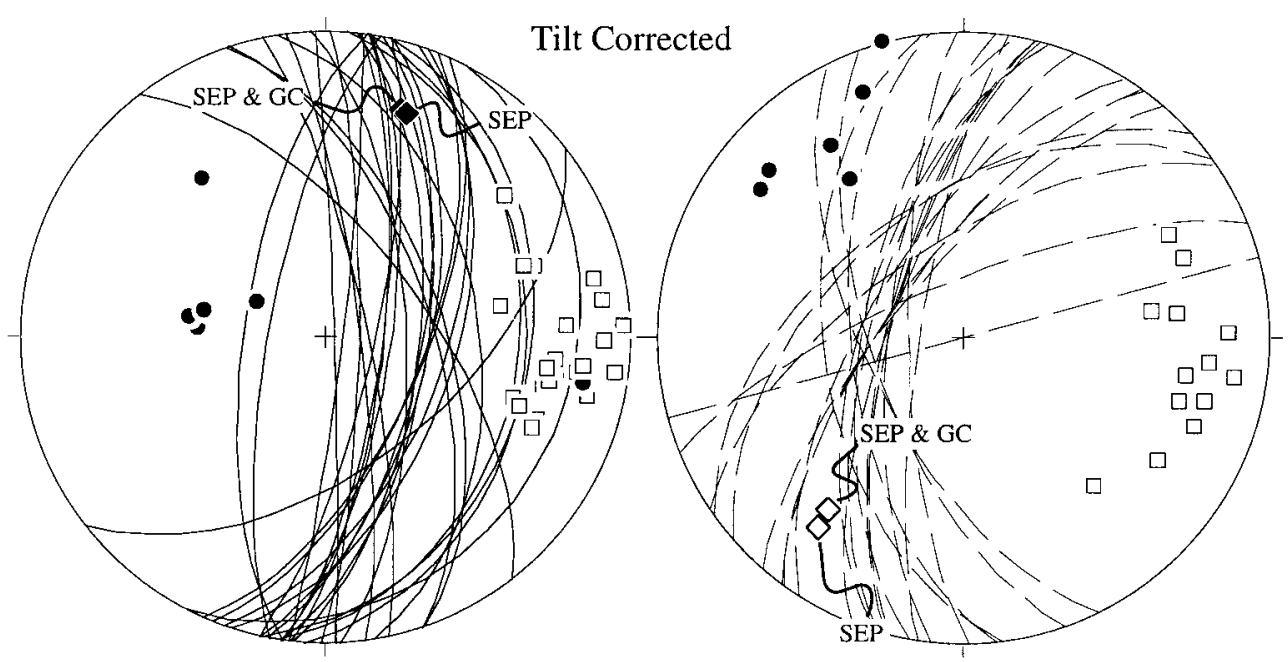

Fig. 5. Equal-area projections of remagnetization great circles in tilt-corrected coordinates on where the characteristic component moves towards normal or reversed polarity directions (panel to the left and to the right, respectively); $S E P \& G C=$ the overall mean direction calculated with the combined analysis of remagnetization great circles (GC) and direct observations (SEP); SEP = the Fisher mean direction calculated only from direct observations. Poles to remagnetization great circles are black circles (white squares) when pointing downward (upward).

lated with marly sandstones and siltstones (10.4 m), and an upper calcareous member consisting of yellowish to brownish marls intercalated with limestone beds $(5.7 \mathrm{~m})$. The Monte Rite section is comprised of, from bottom to top, the lower terrigenous $(3 \mathrm{~m})$ and upper calcareous $(13 \mathrm{~m})$ members of the Dont Fm. followed by $3.92 \mathrm{~m}$ of the Bivera Fm. which is characterized by red and subordinately green marls intercalated with red marly limestones. The boundary between the terrigenous and the calcareous members of the Dont Fm. is well-known in the eastern Dolomites [24] and can be used at a gross scale as a lithostratigraphic marker to correlate the Dont and Monte Rite sections.

\subsection{Biochronology}

The Dont section is the type-locality of the Binodosus Zone $[25,26]$ and of the Pelsonian substage of the Anisian [27]. The lower terrigenous member of the Dont Fm. contains typical Pelsonian ammonoids of the Balatonicus Zone, such as Balatonites and $\mathrm{Bu}$ logites zoldianus. 'Ceratites' binodosus occurs at the top of the lower terrigenous member within level ' $\beta$ ' (Fig. 6). Proavites, Acrochordiceras, Schreyerites,
Discoptychites and Gymnites are also present at some levels [28]. The overlying calcareous member yielded ammonoids of the Trinodosus Zone sensu latu of typical Illyrian age at two new levels. The first level, located $14.4 \mathrm{~m}$ from the base of the section, yielded specimens of Megaceratites, and the second, located $10 \mathrm{~cm}$ above, yielded one doubtful specimen of Paraceratites and several Ptychitidae of the Ptychites indistinctus group. We conclude that the Pelsonian/Illyrian boundary can be placed within an interval of $4 \mathrm{~m}$ between the top of the terrigenous member (where the presence of a small hiatus cannot be excluded), and the base of the Megaceratites level in the calcareous member. Any further chronostratigraphic detail is hardly possible because there is no general agreement on the Pelsonian/Illyrian ammonoid standard scale [29-31]. Conodonts collected in the upper part of the terrigenous member (i.e., from level 'R', Fig. 6) upwards, point to a late Pelsonian/early Illyrian age [32], in broad agreement with ammonoid biostratigraphy.

No ammonoids were collected in the Monte Rite section in this study. A typical Pelsonian fauna of the Balatonicus Zone, with Balatonites, Acrochordiceras and Bulogites, similar to that found in the lower part 


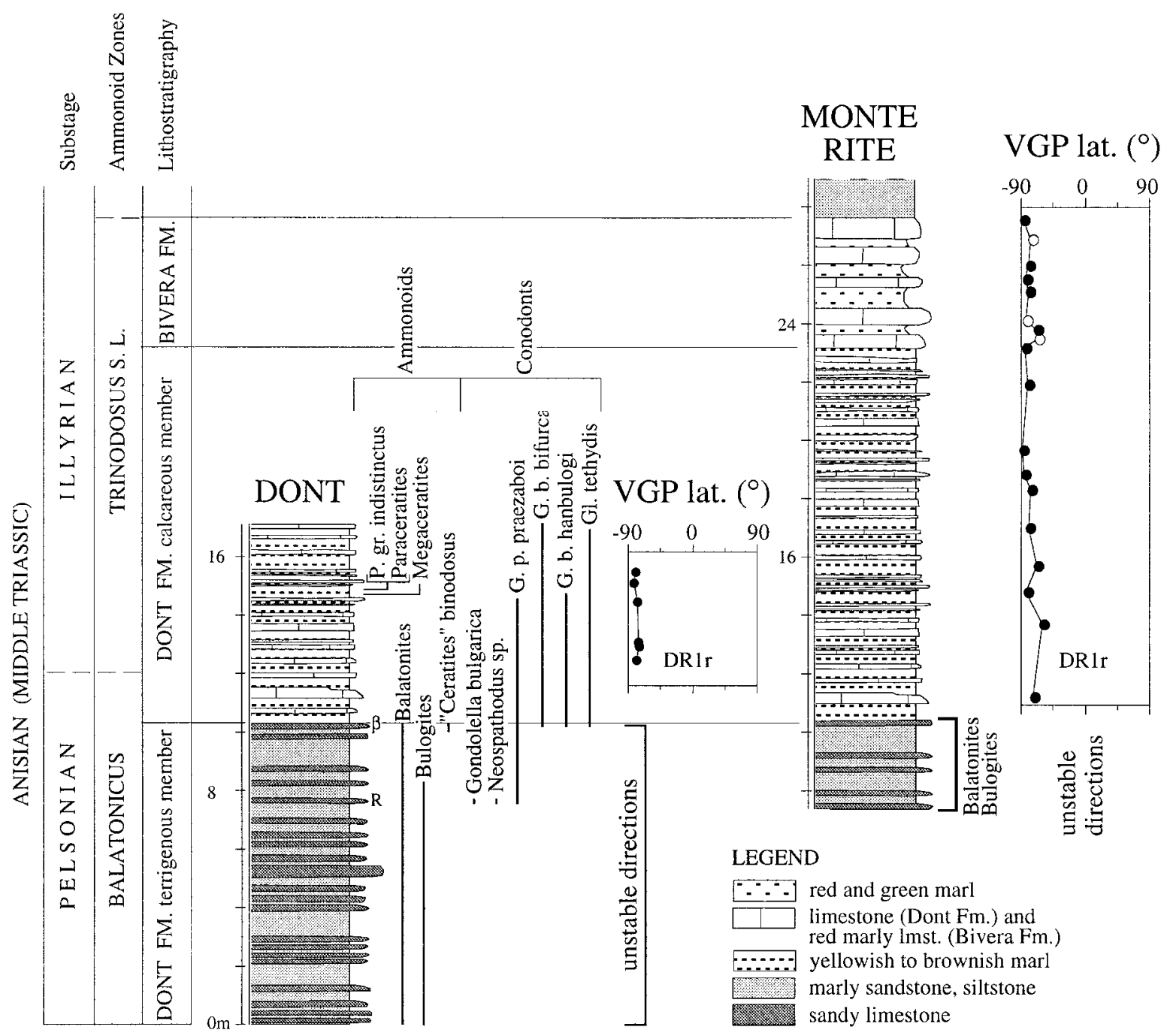

Fig. 6. The Dont and Monte Rite sections with main fossil occurrences and derived ages (M. Balini, A. Nicora), and relative VGP latitudes of the characteristic component plot as a function of stratigraphic position with polarity interpretation. Filled (open) circles are VGP relative latitudes of the characteristic remanence carried by magnetite (mainly hematite); mineralogy is inferred as described in caption to Fig. 3 and in the text.

of the Dont section, was collected by R. Assereto (Milan) at a site located some tens of metres to the northeast of the Monte Rite section in the terrigenous member of the Dont Fm. The overlying Bivera Fm. was assigned to the Illyrian Trinodosus Zone sensu latu [33]. In summary, the Dont-Monte Rite composite section covers a Pelsonian/Illyrian boundary time interval biochronologically comprised of the Balatonicus Zone/Trinodosus Zone sensu latu boundary.

\subsection{Palaeomagnetic properties}

A total of 56 core samples $(2.5 \mathrm{~cm}$ diameter) were drilled, 32 of them at Dont and 24 at Monte Rite. These core samples yielded 44 and 24 standard $11 \mathrm{~cm}^{3}$ specimens for analysis at Dont and Monte Rite, respectively. The initial NRM median intensity is $0.025 \mathrm{~mA} / \mathrm{m}$. Magnetic susceptibility is usually very low but stable during thermal demag- 
netization. Thermal decay of composite IRM points to the presence of magnetite except for the reddish siltstones of the Bivera Fm. which are dominated by hematite. Vector endpoint demagnetograms in insitu coordinates show for all specimens an initial soft component with steep positive inclinations, unblocked between room temperature and about $200^{\circ} \mathrm{C}$, which is generally consistent with acquisition along the present-day field direction. Above this temperature, specimens from the lower terrigenous member of the Dont Fm. at both sections become unstable, and no reliable palaeomagnetic directions could be confidently isolated. From the upper calcareous member upwards we were able to resolve in $18 \%$ and $75 \%$ of the total number of specimens at Dont and Monte Rite, respectively, very steep negative characteristic 'Ch' component directions (Fig. 3e). These directions become southeast and shallow negative after correction for bedding tilt (Fig. 4b; Table 1). The 'Ch' directions are significantly better grouped (at the 99\% level of confidence) after full correction for tilting according to the criteria by McFadden and Jones [34] (Fig. 4c). The overall mean direction is Decl. $=137.1^{\circ}$, Incl. $=-25.8^{\circ}$ which points to an Anisian palaeolatitude of about $14^{\circ} \mathrm{N}$ for the eastern Dolomites.

Magnetostratigraphy, which was interpreted by plotting the latitude of the specimen VGPs vs. stratigraphic thickness as described for the Nderlysaj section, shows that the upper part of the Dont Fm. and the entire Bivera Fm. are part of a reversed polarity interval (named DR1r; Fig. 6).

\section{Correlation of Olenekian/Anisian boundary sections}

We found a dual-polarity component of magnetization of presumed Anisian age at two sections from the Albanian Alps and the Dolomites. North directed and shallow positive magnetizations are interpreted to be of normal polarity. The Olenekian/Anisian (Early/Middle Triassic) boundary interval was recently studied at Chios ([35], and references therein) and Kçira [1]. Our results from Nderysaj and DontMonte Rite extend this record well into the middle Anisian (Illyrian). We propose that the N1n/N1r boundary at Nderlysaj correlates to the $\mathrm{Kç3n} / \mathrm{Kç3r}$ boundary at Kçira, and that most of the Pelsonian and the early Illyrian corresponds to the reversed polarity interval N1r (Fig. 7). The interval of reversed polarity DR1r at Dont-Monte Rite provides important information because it contains typical early Illyrian ammonoids and conodonts which are in agreement with conodont data found at Nderlysaj in the correlative polarity interval N1r. An Illyrian (Trinodosus Zone sensu latu) interval of normal polarity was reported by Muttoni and Kent [36] in the dark Prezzo Limestone outcropping in the western Southern Alps. There is no straightforward correlation yet between the Prezzo Lmst. and the data from the Dont-Monte Rite section. The biostratigraphic age attribution of the Dont-Monte Rite section (i.e., Balatonicus Zone/Trinodosus Zone sensu latu boundary) seems to suggest that at least part of the reversed polarity interval at Dont-Monte Rite, which was correlated with interval N1r at Nderlysaj, should be coeval with the Prezzo Lmst. normal polarity interval. This might imply that the Prezzo Lmst. is remagnetized. However, it is also possible that the Prezzo Lmst. is a little younger than the Dont-Monte Rite section and correlates, say, with interval N2n at Nderlysaj. Sampling of new Tethyan sections will hopefully lead to a resolution of the conundrum.

\section{Towards a better definition of the Middle Triassic polarity reversal sequence}

The data from the Olenekian/Anisian boundary interval from this study and the literature are integrated with data from other Middle Triassic key sections from the literature. The Anisian/Ladinian (Middle Triassic) boundary interval was recently investigated at Hydra (Vlichos and Aghia Triada) and the Dolomites (Frötschbach/Seceda) ([2], and references therein). The Aghia Triada and Frötschbach/ Seceda sections were also correlated with other sections from Austria [37], whereas correlation of the Vlichos section originally proposed in Muttoni et al. [2] seemed problematic [37]. Revisions in the biostratigraphic age attribution and magnetostratigraphic sequence of the Vlichos section of Muttoni et al. [2] prompted by new data could explain the mismatch observed by Gallet et al. [37]. 


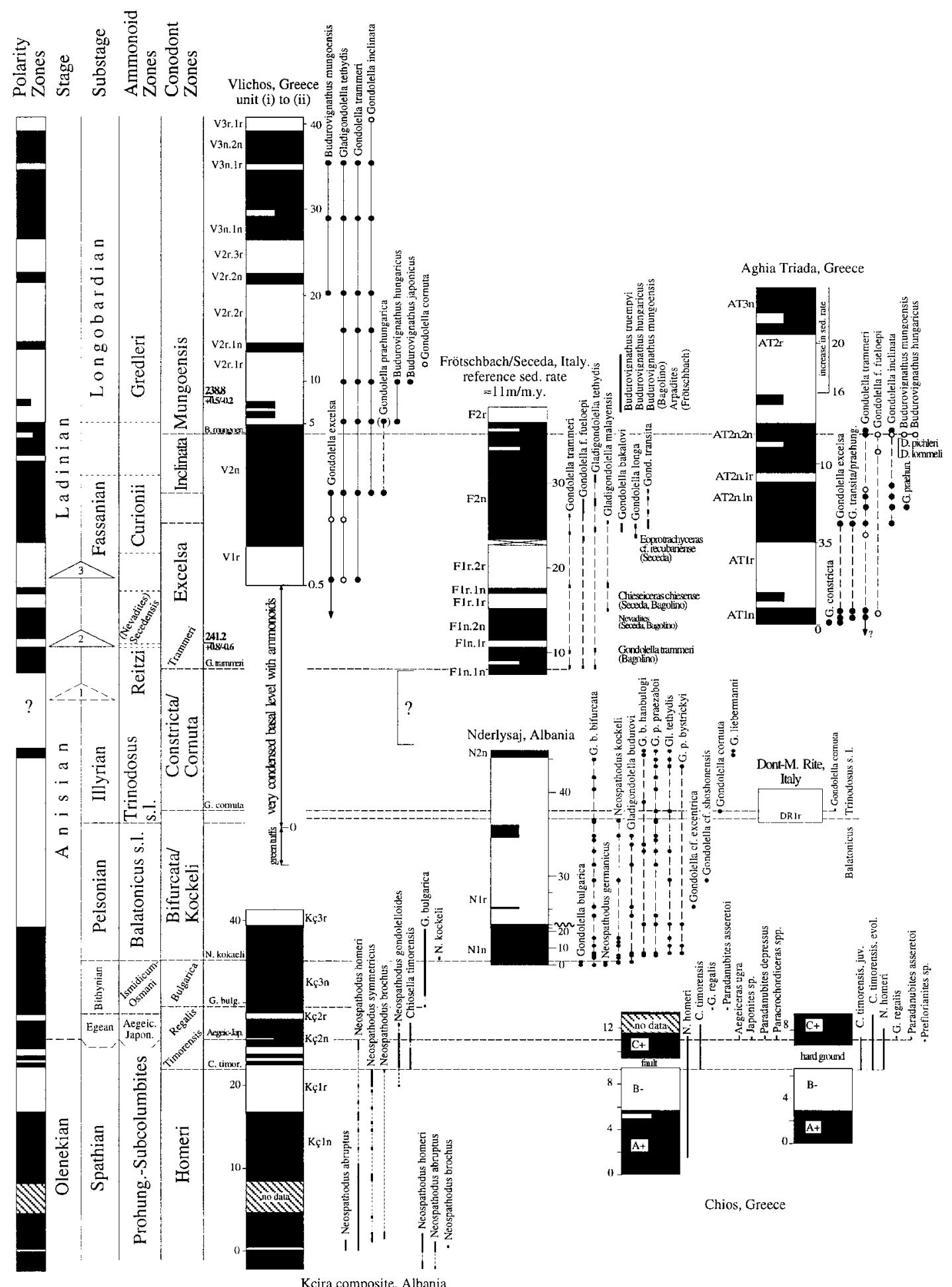




\subsection{Revised biostratigraphy and magnetostratigraphy of the Vlichos section}

Muttoni et al. [2] argued for a mainly late Anisian age for the Vlichos section on the basis of identifications of a poorly preserved ammonoid assemblage and sparse conodont data, as well as lithostratigraphic correlations with other sections on Hydra. In particular, they report a ca. 50-cm-thick extremely condensed level located at very base of lithology (i) (above some tens of metres of tectonized green tuffs with Pelsonian [middle Anisian] conodonts) which yielded Illyrian (late Anisian) ammonoids (Fig. 8). Muttoni et al. [2] also based their age assignment and correlation on the identification of Nevadites sp. ind., which is a proxy for the base of the Ladinian, from a level tentatively located toward the top of the section within lithology (iv). However, one of us (LK) recently resampled the section and found lithologies (i) and (ii) rich in age-diagnostic conodonts of Ladinian age. Accordingly, the age assignments of lithologies (i) and (ii) are as follows: a basal very condensed ammonoid-bearing level of Illyrian to (?) Fassanian (late Anisian to (?) early Ladinian) age is overlain by a condensed 5-m-thick interval of Fassanian (early Ladinian) age which is followed by an expanded 35-m-thick early Longobardian (early-late Ladinian) interval. The base of the Longobardian is placed at metre 5 at the FO of Gondolella inclinata (Fig. 8). Specimens of Gondolella pseudolonga of early Fassanian and older age were found within lithology (iii) a few decimetres below the supposed location of the Nevadites-bearing level. Therefore, lithologies (iii) to (v) are probably of older age than lithologies (i) and (ii), and the tectonic discontinuity that separates lithology (ii) from lithology (iii) is a major fault that duplicates the series, rather than an inverse fault of minor importance as reported by Muttoni et al. [2]. Nevertheless, the very poor biostratigraphic age attribution of the short lithology (iii) to (v) subsection does not allow a more certain correlation (see also caption to Fig. 8).

\subsection{A composite Middle Triassic polarity sequence}

The composite sequence of polarity reversals of this study and the literature is based on nominal sedimentation rate for nodular limestones derived from estimates for well-dated sections rather than on the assumption of equal duration of biozones (Fig. 7). An average sedimentation rate of about $11 \mathrm{~m} / \mathrm{m} . \mathrm{y}$. was established for the Frötschbach/Seceda section based on radiometric age data [2,38]. By means of magnetostratigraphic correlation, this value is found to be broadly consistent also with the lower $16 \mathrm{~m}$ of nodular limestone beds of the coeval Aghia Triada section (i.e., about $7 \mathrm{~m} / \mathrm{m}$.y.), whereas the upper part of the Aghia Triada section bearing carbonate platform-derived calcarenites is probably characterized by higher sedimentation rates. A nominal sedimentation rate of about $11 \mathrm{~m} / \mathrm{m}$.y. is then given to the other sections of this study and to those in the literature which bear nodular limestone beds lithologically similar to Aghia Triada.

The condensed nodular limestones of Fassanian age of Vlichos lithology (i) were correlated with Frötschbach/Seceda and Aghia Triada by means of biostratigraphy and magnetostratigraphy, thus implying a nominal sedimentation rate which is about four times lower than the reference value of Frötschbach/ Seceda. The expanded calcarenite levels of carbonate platform origin found at Nderlysaj in the lower half of the section were correlated with Kçira using similar criteria (FO of Neospathodus kockeli and magnetostratigraphy), and the nominal sedimentation rate was found to be about five times higher than the reference value of Frötschbach/Seceda. Finally, we estimate the sedimentation rate of the Dont-Monte Rite section to be at least on the order of several tens of metres per million years, mainly because of the

Fig. 7. Comparison of magnetostratigraphic and biostratigraphic data from this study and the literature for the Early-Middle Triassic of the Tethys realm. The Nderlysaj and Dont-Monte Rite sections only partly straddle a gap of data between the Spathian to Pelsonian Chios and Kçira sections (lower part of figure, [1]), and the Illyrian to Longobardian Vlichos, Aghia Triada and Frötschbach/Seceda sections (upper part of figure, [2], and this study). The composite magnetic polarity stratigraphy is reported to the left of figure. The three alternative options for the position of the base of the Ladinian are indicated (1, base of the Reitzi Zone, which probably falls in the Illyrian gap of data; 2, base of the Secedensis Zone; 3, base of the Curionii Zone). The magnetozones are reported in thickness. 


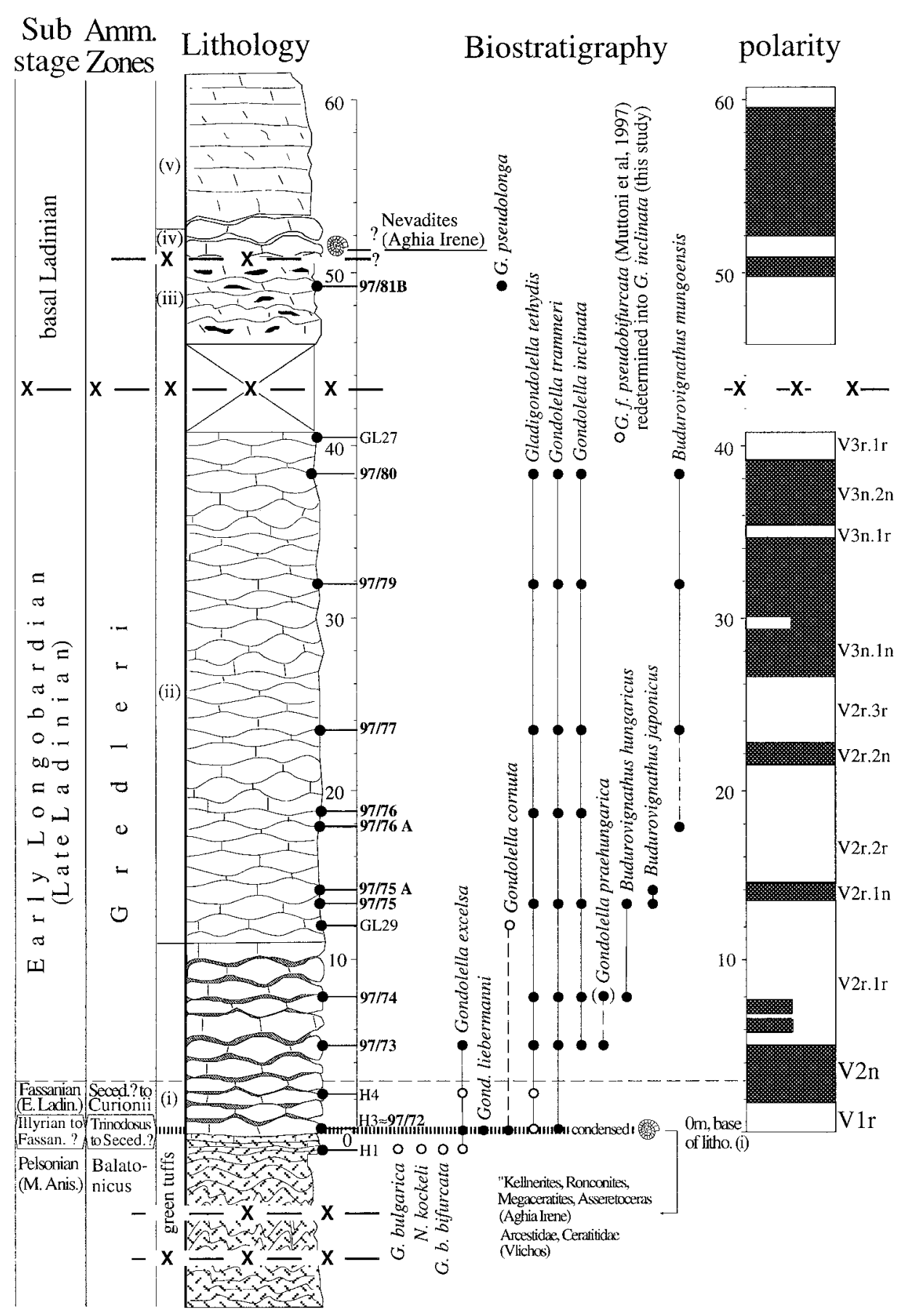

Fig. 8. The Vlichos section of Muttoni et al. [2] with new conodont data and derived age from this study (L. Krystyn). In the biostratigraphy section filled (open) symbols refer to data from this study (from Ref. [2]). The polarity interpretation column, where magnetic polarity zones are shown by filled/open bars for normal/reversed polarity, is also reported to the right of figure. Note that the polarity interpretation of the lithology (iii) to (v) subsection was inadvertently inverted in Muttoni et al. [2]. 
important terrigenous input that characterizes this type of facies. A gap of data representing part of the Illyrian substage is present between the Olenekian/ Anisian and the Anisian/Ladinian boundary sections. This data gap of uncertain extent prevents us from making precise estimates of reversal frequency and duration of the Olenekian-Ladinian composite polarity sequence. Moreover, it is still difficult to incorporate or even correlate the magnetic polarity stratigraphy from mainly continental redbed sections from eastern Spain and the western US [39] because of the limited and endemic biostratigraphic control and the generally lower sampling resolution in the available continental sequences for the Middle Triassic.

\section{Tectonic interpretation}

Triassic deep-water limestone facies from the Dolomites, Albania and Greece from this study and the literature $[1,2,35]$ were deposited in Neotethyan rift basins which developed along the northern margin of Gondwana in the western Tethys as consequence of the Triassic Cimmerian tectonics (e.g., [40]). The northern margin of Gondwana in the western Tethys was located essentially north of the Equator during the Middle Triassic [41]. The ' $\mathrm{Ch}$ ' palaeomagnetic poles found at Nderlysaj and DontMonte Rite, as well as Kçira [1], Chios [35] and Hydra (Aghia Triada and Vlichos) [2], were therefore acquired north of the Equator and should have an affinity with the West Gondwana apparent polar wander path (APWP) or should lie somewhere in between the West Gondwana and Europe APWPs. However, the overall characteristic direction at Nderlysaj defines a palaeomagnetic North Pole at $52.7^{\circ} \mathrm{N}, 148.8^{\circ} \mathrm{E}$ (Table 1) which falls close to the Triassic portion of the Europe APWP at only $8.4^{\circ}$ of angular distance from the roughly coeval Kçira palaeopole from Albania [1] (Fig. 9a). We propose a model based on in situ vertical-axis tectonic rotations that takes into account also ' $\mathrm{B}$ ' component palaeopoles to explain the discrepancy between observed and expected 'Ch' palaeopole positions. We assume that the Triassic ' $\mathrm{Ch}$ ' and younger ' $\mathrm{B}$ ' component palaeopoles from this study and the literature were originated at or close to the West Gondwana
APWP. The age of acquisition of the 'B' component palaeopole from Nderlysaj is not constrained by field tests; however, it is here conservatively considered postfolding because in in-situ coordinates it is by far less removed from any reference palaeopole then after correction for bedding tilt. The 'B' component palaeopoles from Chios and Hydra have been proved to be synfolding and postfolding in age, respectively. Deformation in this part of the Albania-Greece Alpine belt commenced as early as in the Early Cretaceous and continued into the Cenozoic. Accordingly, the syn-postfolding ' $\mathrm{B}$ ' component palaeopoles when rotated onto the West Gondwana APWP are compatible with Late Cretaceous/ early Cenozoic reference palaeopoles (Fig. 9b).

The angular distance between the Nderlysaj ' $\mathrm{Ch}$ ' and in situ ' $\mathrm{B}$ ' component palaeopoles, and the Triassic and early Cenozoic reference Africa palaeopoles is about $43^{\circ}$ and $73^{\circ}$ clockwise, respectively. The resulting difference between the ' $\mathrm{Ch}$ ' palaeopole and the reference Triassic palaeopoles must be therefore explained with pre-'B' counterclockwise rotations. We propose that Nderlysaj (and presumably also Kçira) and Chios were first rotated counterclockwise by about $30^{\circ}$ and $43^{\circ}$ with respect to West Gondwana, respectively, whereas the Aghia Triada and Vlichos (i)-(ii) palaeopoles from Hydra indicate that these areas were rotated clockwise by $125^{\circ}$ (Fig. 9b). All these rotations occurred prior to the acquisition of the ' $\mathrm{B}$ ' component, perhaps in association with the Triassic Cimmerian tectonics (e.g., [40]) (Fig. 9b). Rotations continued after acquisition of the ' $\mathrm{B}$ ' component in the Cenozoic: an additional $25^{\circ}$ counterclockwise rotation of presumed Neogene age is observed at Chios [35] and about $73^{\circ}$ clockwise rotation is observed at Nderlysaj and occurred presumably also at Kçira (Fig. 9a). About 40-45 of the rotations at Nderlysaj and Kçira may be related to the rotation of the external zone of Albania since the Early-Middle Miocene ([6,7], and references therein; see also Ref. [1]). Hydra experienced a similar $45^{\circ}$ clockwise rotation after acquisition of the ' $\mathrm{B}$ ' component which may also be related to this late Cenozoic tectonic phase in the external part of Greece [6,42] (Fig. 9a).

Finally, the palaeomagnetic pole for the DontMonte Rite characteristic directions falls at $41^{\circ} \mathrm{N}$, $254^{\circ} \mathrm{E}$ (Table 1) and is displaced counterclockwise 


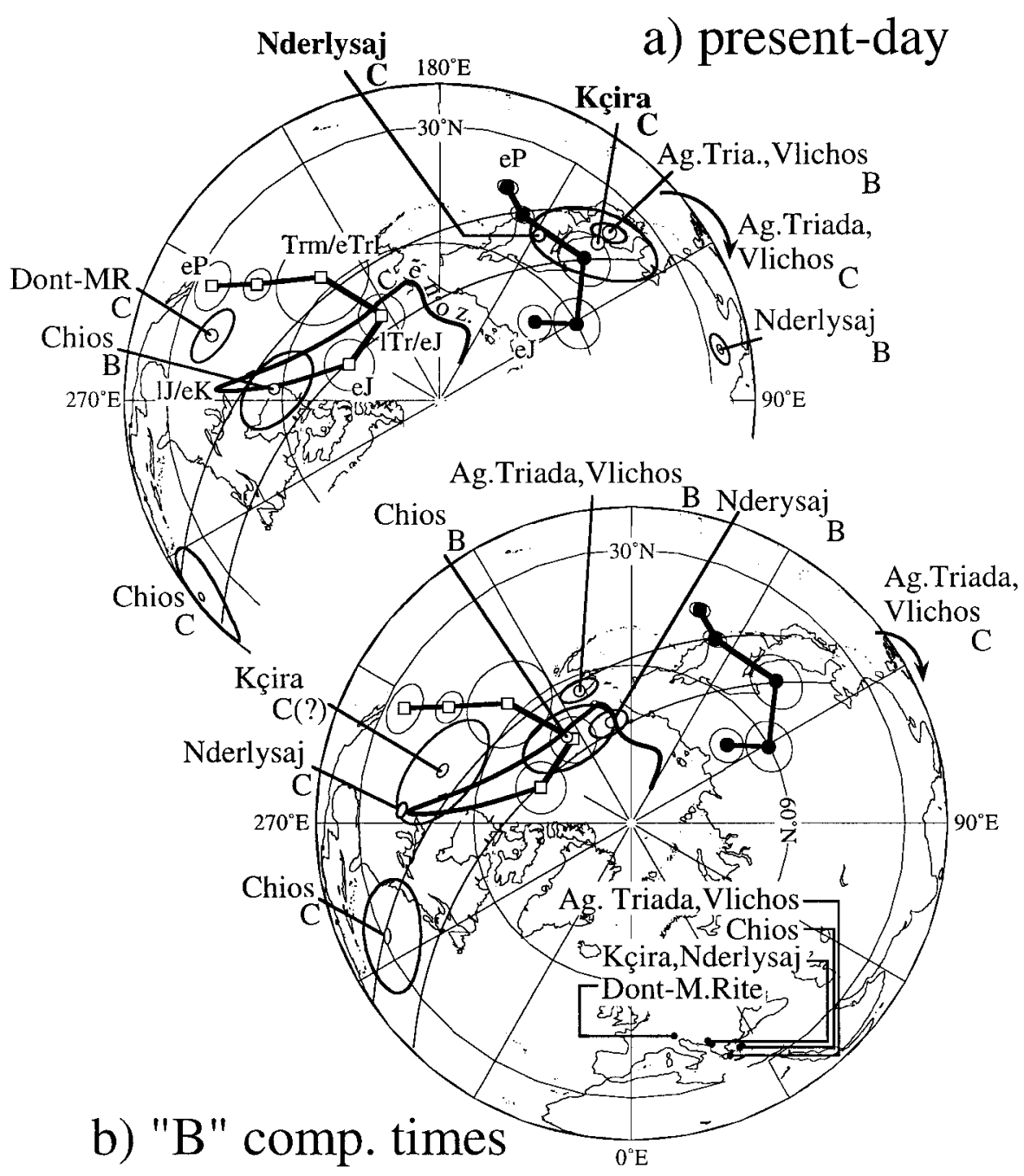

Fig. 9. The palaeomagnetic poles from Nderlysaj and Dont-Monte Rite and from other regions in the Mediterranean (Chios, Greece; Aghia Triada and Vlichos from Hydra, Greece; Kçira, Albania) are compared with the West Gondwana and Europe apparent polar wander paths (white squares and solid circles, respectively) [41]. The suffix attached to the pole designation refers to the magnetization component used to calculate the pole: $C=$ the characteristic component, $B=$ a secondary component. In panel (a) are the present-day positions of the characteristic and 'B' component palaeopoles, and in panel (b) are the presumed position of the characteristic component palaeopoles at the times of acquisition of the ' $\mathrm{B}$ ' component palaeopoles onto the West Gondwana polar wander path. The solid lines are small circles centred on the eastern Mediterranean and illustrate that vertical axis rotations can account for the dispersion of these palaeopoles. See text for discussion.

by about $25^{\circ}$ with respect to other Middle Triassic poles from the literature from the Southern Alps [41]. This displacement could be due to a local tectonic rotation of the Dont-Monte Rite area relative to other regions of the Southern Alps which are usually considered to have a West Gondwana affinity (e.g., [41]) (Fig. 9a).

\section{Conclusions}

We have presented data that, in conjunction with results from the literature, allow us to define the main magnetostratigraphic features of the Olenekian/ Anisian and the Anisian/Ladinian boundary intervals. A total of 29 biostratigraphically calibrated 
reversals are thus far recognized over the late-Early Triassic to late-Middle Triassic interval of perhaps $10-15$ m.y. length. Additional studies are still needed to fill a data gap in the Illyrian which presently exists between the top of the Ndrelysaj section and the base of Frötschbach/Seceda. Finally, palaeomagnetic pole position analysis indicates that a complex history of clockwise and counterclockwise tectonic rotations occurred in the Balkan-Aegean region since Triassic times.

\section{Acknowledgements}

This research was partially founded by the Centro per la Geodinamica Alpina e Quaternaria, CNR, Milan. We thank Roberto Molina-Garza and an anonymous reviewer for constructive reviews of the manuscript. [RV]

\section{References}

[1] G. Muttoni, D.V. Kent, S. Meço, A. Nicora, M. Gaetani, M Balini, D. Germani, R. Rettori, Magneto-biostratigraphy of the Spathian to Anisian (Lower to Middle Triassic) Kçira Section, Albania, Geophys. J. Int. 127 (1996) 503-514.

[2] G. Muttoni, D.V. Kent, P. Brack, A. Nicora, M. Balini, Middle Triassic magneto-biostratigraphy from the Dolomites and Greece, Earth Planet. Sci. Lett. 146 (1997) 107-120.

[3] ISPGJ-ISGJN, Gijeologjia e Shqiperise (Geology of A1bania), Industry, Mines and Energy Ministry of Albania, Tirana, 1982.

[4] ISPGJ-ISGJN, Harta Gijelogjike e Shqiperise (Geological map of Albania), Scale 1:200,000, Industry, Mines and Energy Ministry of Albania, Tirana, 1983.

[5] J. Dercourt, Sur 1'accident de Scutari-Pec, la signification paléogéographique de quelques séries condensées en Albanie septentrionale, Ann. Soc. Géol. Nord 9 (1967) 1109.

[6] F. Speranza, I. Islami, C. Kissel, A. Hyseni, Paleomagnetic evidence for Cenozoic clockwise rotation of the external Albanides, Earth Planet. Sci. Lett. 129 (1995) 121-134.

[7] H.J. Mauritsch, R. Scholger, S.L. Bushati, H. Ramiz, Palaeomagnetic results from southern Albania and their significance for the geodynamic evolution of the Dinarides, Albanides and Hellenides, Tectonophysics 242 (1995) 518.

[8] S. Kovács, H. Kozur, Stratigraphische Reichweite der wichtigsten Conodonten (ohne Zahnreihen-Conodonten) der Mittel- und Obertrias, Geol. Paleontol. Mitt. Innsbruck 10 (2) (1980) 42-78.

[9] W.C. Sweet, The Conodonta, Oxford Monographs on Geol- ogy and Geophysics 10, Oxford University Press, Oxford, 1988.

[10] R. Rettori, Foraminiferi del Trias Inferiore e Medio della Tetide: revisione tassonomica, stratigrafia ed interpretazione filogenetica, Genève, 1995, 150 pp.

[11] L. Zaninetti, Le Foraminifères du Trias, Riv. Ital. Paleontol. 82 (1) (1976) 1-258.

[12] E. Trifonova, Taxonomy of Bulgarian Triassic Foraminifera, I, Families Psammospheridae to Nodosinellidae, Geol. Balc. 22 (1) (1992) 3-50.

[13] J. Salaj, Essai de zonations dans le Trias des Carpates Occidentales d'après les foraminifères, Geol. Prace 48 (1969) 123-128.

[14] J. Salaj, E. Trifonova, D. Gheorghian, A biostratigraphic zonation based on benthic foraminifera in the Triassic deposits of the Carpatho-Balkans, Rev. Paléobiol. Vol. Spéc. 2 (1988) 153-159.

[15] J. Salaj, K. Borza, O. Samuel, Triassic foraminifers of the West Carpathians, Geol. Ustav Dinyza Stura, 1983, 213 pp.

[16] P. Brönnimann, J.P. Cadet, L. Zaninetti, Sur la présence d'Involutina sinuosa prasoides (Oberhauser) (Foraminifère) dans l'Anisien supérieur probable de Bosnie-Herzegovine méridionale (Yougoslavie), Riv. Ital. Paleontol. 79 (3) (1973) 301-336.

[17] A. Gazdzicki, J. Trammer, K. Zawidzka, Foraminifers from the Muschelkalk of Southern Poland, Acta Geol. Pol. 25 (2) (1975) 285-298.

[18] L. Zaninetti, R. Rettori, R. Martini, Aulotortus? eotriasicus, n. sp., un nuovo foraminifero del Trias medio (Anisico) delle Dinaridi ed Ellenidi, Boll. Soc. Paleontol. Ital. 33 (1) (1994) 43-49.

[19] R. Rettori, L. Angiolini, G. Muttoni, Lower and Middle Triassic foraminifera from the Eros Limestone, Hydra Island, Greece, J. Micropaleontol. 13 (1994) 25-46.

[20] W. Lowrie, Identification of ferromagnetic minerals in a rock by coercivity and unblocking temperature properties, Geophys. Res. Lett. 17 (1990) 159-162.

[21] J.L. Kirschvink, The least-squares line and plane and the analysis of palaeomagnetic data, Geophys. J. R. Astron. Soc. 62 (1980) 699-718.

[22] P.L. McFadden, M.W. McElhinny, The combined analysis of remagnetization circles and direct observations in palaeomagnetism, Earth Planet. Sci. Lett. 87 (1988) 161172.

[23] D.V. Kent, P.E. Olsen, W.K. Witte, Late Triassic-earliest Jurassic geomagnetic polarity sequence and paleolatitudes from drill cores in the Newark rift basin, eastern North America, J. Geophys. Res. 100 (1995) 14965-14998.

[24] G. Pisa, E. Farabegoli, E. Ott, Stratigrafia e paleogeografia dei terreni anisici della conca di Agordo e dell'alta Val di Zoldo (Dolomiti sudorientali), Mem. Soc. Geol. Ital. 18 (1978) (1979) 63-92.

[25] E.v. Mojsisovics, Die Dolomitriffe von Südtirol und Venetien, Wien, 1879, $552 \mathrm{pp}$.

[26] E.v. Mojsisovics, Die Cephalopoden der Mediterranen Triasprovinz, Abh. k. k. Geol. Reichsanst. 10 (1882) 1-322. 
[27] J. Pia, Grundbegriffe der Stratigraphie, Franz Deuticke, Wien, 1930, $252 \mathrm{pp}$.

[28] M. Balini, Preliminary report on the Pelsonian ammonoids from the Dont section (Eastern Dolomites), Riv. Ital. Paleontol. Strat. 99 (2) (1993) 263-270.

[29] A. Vörös, Preliminary results from the Aszofö section (Middle Triassic, Balaton area, Hungary): a proposal for a new Anisian ammonoid subzonal scheme, Fragm. Min. Palaeontol. 13 (1987) 53-64.

[30] M. Balini, M. Gaetani, A. Nicora, Day 2, in: M. Gaetani (Ed.), Anisian/Ladinian Boundary Field Workshop, Milano, 1993, pp. 43-54.

[31] P. Mietto, S. Manfrin, A high resolution Middle Triassic ammonoid standard scale in the Tethys realm, A preliminary report, Bull. Soc. Geol. Fr. 166 (5) (1995) 539-563.

[32] S. Kovács, J. Papsová, M.C. Perri, New Middle Triassic conodonts of the Gondolella szabói-G. trammeri lineage from the Western Carpathian Mts and the Southern Alps, Acta Geol. Hung. 39 (1) (1996) 103-128.

[33] E. Farabegoli, D. Levanti, M.C. Perri, P. Veneri, M Bivera Formation: an atypical Middle Triassic 'Rosso Ammonitico' facies from the Southern Alps (Italy), G. Geol. 46 (2) (1984) 33-46.

[34] P.L. McFadden, D.L. Jones, The fold test in palaeomagnetism, Geophys. J. R. Astron. Soc. 67 (1981) 53-58.

[35] G. Muttoni, D.V. Kent, M. Gaetani, Magnetostratigraphy of a Lower/Middle Triassic boundary section from Chios (Greece), Phys. Earth Planet. Inter. 92 (1995) 245-261.
[36] G. Muttoni, D.V. Kent, Paleomagnetism of latest Anisian (Middle Triassic) sections of the Prezzo Limestone and the Buchenstein Formation, Southern Alps, Italy, Earth Planet. Sci. Lett. 122 (1994) 1-18.

[37] Y. Gallet, L. Krystyn, J. Besse, Upper Anisian to Lower Carnian magnetostratigraphy from the northern calcareous Alps (Austria), J. Geophys. Res. 103 (B1) (1998) 605-621.

[38] R. Mundil, P. Brack, M. Meier, H. Rieber, F. Oberli, High resolution $\mathrm{U}-\mathrm{Pb}$ dating of Triassic volcaniclastics: timescale calibration and verification of tuning parameters for carbonate sedimentation, Earth Planet. Sci. Lett. 141 (1996) 137-151.

[39] R.S. Molina-Garza, J.W. Geissman, R. Van der Voo, S.G. Lucas, S.N. Hayden, Paleomagnetism of the Moenkopi and Chinle Formations in central New Mexico: implications for the North American apparent polar wander path and Triassic magnetostratigraphy, J. Geophys. Res. 96 (B9) (1991) 14239-14261.

[40] J.E. Dixon, A.H.F. Robertson (Eds.), The Geological Evolution of the Eastern Mediterranean, Geol. Soc. London Spec. Publ. 17 (1984) 824 pp.

[41] G. Muttoni, D.V. Kent, J.E.T. Channell, Evolution of Pangea: paleomagnetic constraints from the Southern Alps, Italy, Earth Planet. Sci. Lett. 140 (1996) 97-112.

[42] C. Kissel, C. Laj, Tertiary geodynamical evolution of the Aegean arc: a paleomagnetic reconstruction, Tectonophysics 146 (1988) 183-201. 